\title{
Growth, Sugar Yield, Quality and Economics of Sugarcane under Different Establishment Techniques and Planting Geometries
}

\author{
Maruthi $^{1}$, D. Krishnamurthy ${ }^{2 *}$, Y.M. Ramesh ${ }^{3}$, \\ B.M. Chittapur ${ }^{1}$ and Ashokkumar Gaddi ${ }^{4}$ \\ ${ }^{1}$ Department of Agronomy, College of Agriculture, Raichur, India \\ ${ }^{2}$ Agricultural Research Station, Hagari, India \\ ${ }^{3}$ Agricultural Research Station, Dhadesugur, India \\ ${ }^{4}$ Agricultural Research Station, Siruguppa, Karnataka, India \\ *Corresponding author
}

\begin{tabular}{l}
$\begin{array}{l}\text { Ke y w o r d s } \\
\text { Planting techniques } \\
\text { and geometries, } \\
\text { Quality setts, } \\
\text { Sugarcane, Sugar } \\
\text { yield }\end{array}$ \\
\hline Article Info \\
\hline $\begin{array}{l}\text { Accepted: } \\
\text { 07 October } 2019 \\
\text { Available Online: } \\
10 \text { November } 2019\end{array}$ \\
\hline
\end{tabular}

\section{A B S T R A C T}

A Field experiment was carried out in a black clay [the soil was slightly alkaline $\mathrm{pH}$ (8.23), low in EC $\left(0.20 \mathrm{dSm}^{-1}\right)$ and organic carbon $(0.43 \%)$, low in available nitrogen $\left(166.8 \mathrm{~kg} \mathrm{ha}^{-1}\right)$, high in available phosphorus $\left(55.0 \mathrm{~kg} \mathrm{ha}^{-1}\right)$ and available potassium $\left(300.5 \mathrm{~kg} \mathrm{ha}^{-1}\right)$ ] soil to study the growth, sugar yield, quality and economics of sugarcane under different establishment techniques and planting geometries at Experimental block, Agricultural Research Station, Dhadesugur which falls under Northern Dry Zone of Karnataka (Zone-III) during 2016-17. Ten treatments were evaluated in different planting techniques and planting geometries in randomized block design with three replications. Among different treatments Two eye budded setts with dual row planting $(30 \mathrm{~cm}-150 \mathrm{~cm}-30 \mathrm{~cm})$ was recorded significantly highest sugar yield $\left(15.2 \mathrm{t} \mathrm{ha}^{-1}\right)$, green biomass yield $\left(16.2 \mathrm{t} \mathrm{ha}^{-1}\right)$, number of leaves $\left(20.7\right.$ plant $\left.^{-1}\right)$, leaf, stem and total dry matter production (72.6, 342.1 and $414.6 \mathrm{~g} \mathrm{plant}^{-1}$, respectively) and which was on par with Two eye budded setts with paired row planting $(60 \mathrm{~cm}-120 \mathrm{~cm}-60 \mathrm{~cm})$ and Two eye budded setts with wide row planting $(120 \mathrm{~cm})$. The lowest sugar yield $\left(10.4 \mathrm{tha}^{-1}\right)$, green biomass yield $\left(11.9 \mathrm{t} \mathrm{ha}^{-1}\right)$, number of leaves $\left(17.0\right.$ plant $\left.^{-1}\right)$, leaf, stem and total dry matter production $\left(61.4,320.6\right.$ and 382.0 g plant $^{-1}$, respectively) was recorded with Three eye budded setts with conventional planting $(90 \mathrm{~cm})$. While brix $\%$, pol $\%$,purity co-efficient $\%$ and commercial cane sugar $\%$ remained non-significant by different planting techniques and planting geometries. Two eye budded setts with dual row planting recorded higher gross returns (Rs. $411493 \mathrm{ha}^{-1}$ ) followed by two eye budded setts with paired row planting (Rs. $390780 \mathrm{ha}^{-1}$ ) and two eye budded setts with wide row planting (Rs. $385320 \mathrm{ha}^{-1}$ ). 


\section{Introduction}

Globally, sugarcane is cultivated in an area of $24.5 \mathrm{~m}$ ha with a production of $1850 \mathrm{~m} \mathrm{t}$ and a productivity of $75.5 \mathrm{t} \mathrm{ha}^{-1}$ (Anon, 2015). In India, sugarcane is grown in Maharashtra, Karnataka, Gujarat, Tamil Nadu, Uttar Pradesh, Punjab, Haryana and Bihar. India is the world's second largest producer of sugarcane in terms of area $(5.3 \mathrm{~m} \mathrm{ha})$ of world's total sugar production $(27.1 \mathrm{~m} \mathrm{t})$. In Karnataka, it is cultivated in an area of about $0.50 \mathrm{~m}$ ha with a production of $47 \mathrm{~m} \mathrm{t}$ and a productivity of $94.0 \mathrm{t} \mathrm{ha}^{-1}$ (Anon., 2015a).Of the many variables involved in the production of higher cane and sugar yield from sugarcane plant, probably the most important factor is the millable canes per unit area of land at harvest, which can be achieved by manipulating planting geometry/density to greater extent by way of maximizing efficient interception of incident radiant energy. Since, closer spacing hinders the mechanized intercultural operation; adoption of wider spacing is increasing in many parts of India. In recent past wider row spacing is very popular as it helps mechanization of several field operations thereby results in minimization cost of production. However, as spacing increases, number of millable canes can become a limiting factor in sugarcane productivity (Singh et al., 2006).

The primary components of cane yield arecane population and weight of individual cane. Cane population per unit area is directly affected by planting density which changes rapidly with the closer spacing or with the increase in seed rate. Thus, yield level can be increased substantially by manipulating certain cultural practices like spacing, planting material etc. The adaption of optimum spacing, suitable planting pattern/ crop geometry, sett size and sett rate will go a long way in increasing yield and quality of sugarcane. The information on testing of different planting material under various planting techniques is lacking and needs to be worked out. It is, therefore, necessary to standardize the suitable planting techniques with spacing/ plant geometry that may improve the quality, productivity and profitability of sugarcane.

\section{Materials and Methods}

A Field experiment was carried out in a black clay [the soil was slightly alkaline $\mathrm{pH}$ (8.23), low in EC $\left(0.20 \mathrm{dSm}^{-1}\right)$ and organic carbon $(0.43 \%)$, low in available nitrogen $(166.8 \mathrm{~kg}$ $\left.\mathrm{ha}^{-1}\right)$, high in available phosphorus $(55.0 \mathrm{~kg}$ $\left.\mathrm{ha}^{-1}\right)$ and available potassium (300.5 $\left.\left.\mathrm{kg} \mathrm{ha}^{-1}\right)\right]$ study the growth, sugar yield, quality and economics of sugarcane under different establishment techniques and planting geometries at Experimental block, Agricultural Research Station, Dhadesugur which falls under Northern Dry Zone of Karnataka (Zone-III) during 2016-17. The station is situated between $15^{\circ} 41^{\prime} \mathrm{N}$ latitude, $76^{\circ} 53^{\prime} \mathrm{E}$ longitude and at an altitude of 380 meters above mean sea level. The composite soil samples from 0 to $15 \mathrm{~cm}$ depth were collected before planting and at harvest. Soils were air dried in shade, powdered and passed through $2 \mathrm{~mm}$ sieve and analysed for $\mathrm{pH}, \mathrm{EC}$, OC, available $\mathrm{N}, \mathrm{P}_{2} \mathrm{O}_{5}$ and $\mathrm{K}_{2} \mathrm{O}_{5}$ by following the methods described by Jackson (1973) and Lindsay and Norvel (1978). The experiment comprised of ten treatments viz. $\mathrm{T}_{1}$-Single eye budded setts with wide row planting $(120 \mathrm{~cm}$ furrow), $\mathrm{T}_{2}$ : Single eye budded setts with paired row planting $(60 \mathrm{~cm}-120 \mathrm{~cm}-60 \mathrm{~cm})$, $\mathrm{T}_{3}$ : Single eye budded setts with dual row planting $(30 \mathrm{~cm}-150 \mathrm{~cm}-30 \mathrm{~cm}), \mathrm{T}_{4}$ : Two eye budded setts with wide row planting $(120 \mathrm{~cm})$, $\mathrm{T}_{5}$ : Two eye budded setts with paired row planting $(60 \mathrm{~cm}-120 \mathrm{~cm}-60 \mathrm{~cm}), \mathrm{T}_{6}$ : Two eye budded setts with dual row planting $(30 \mathrm{~cm}$ $150 \mathrm{~cm}-30 \mathrm{~cm}), \mathrm{T}_{7}$ : Bud chip seedlings with wide row planting (120 cm furrow), $\mathrm{T}_{8}$ : Bud chip seedlings with paired row planting (60 
cm- $120 \mathrm{~cm}-60 \mathrm{~cm}), \mathrm{T}_{9}$ : Bud chip seedlings with dual row planting $(30 \mathrm{~cm}-150 \mathrm{~cm}-30$ $\mathrm{cm})$ and $\mathrm{T}_{10}$ : Three eye budded setts with conventional planting $(90 \mathrm{~cm})$. The experiment was laid out in randomized complete block design (RCBD) with three replications. The sugarcane variety $2003-\mathrm{V}-46$ was planted on $1^{\text {st }}$ of February, 2016. Fertilizer was applied @ 250 kg N, 100 $\mathrm{kgP}_{2} \mathrm{O}_{5}$ and $125 \mathrm{kgK}_{2} \mathrm{Oha}^{-1}$ in the form of Urea, DAP, and SOP, respectively. The entire dose of $\mathrm{P}, \mathrm{K}$, and $1 / 3$ rd of $\mathrm{N}$ were applied as a basal dose at the time of planting, while remaining $\mathrm{N}$ was applied in two splits, 1/3rd at the start of tillering and 1/3rd before earthing up by side dressing. The crop was harvested manually after its maturity on $29^{\text {th }}$ of February, 2017. Recommended packages of practices were adopted for crop production. Five randomly selected canes at harvest were weighed and crushed to extract the juice and used for analyzing the quality parameters using standard procedures. Sugar yield was calculated by using the formula as suggested by Sastry and Venkatachari (1960). It is the product of commercial cane sugar (\%) and cane yield $\left(\mathrm{t} \mathrm{ha}^{-1}\right)$. The cost of inputs, labour charges and prevailing market rates of farm produce were taken into consideration for working out cost of cultivation, gross returns and net returns per hectare. The net returns were calculated by deducting cost of cultivation from gross returns. The analysis and interpretation of data were done using the Fisher's method of analysis and variance technique as given by Gomez and Gomez (1984).

\section{Results and Discussion}

\section{Growth parameters}

Significantly higher number of leaves was observed in two eye budded setts with dual row planting (20.7). Whereas, lower number of leaves were recorded with three eye budded setts with normal row planting (17.0). The dry matter accumulations in leaf, cane and plant at different growth stages (Table 1) were higher under $30 \mathrm{~cm}-150 \mathrm{~cm}-30 \mathrm{~cm}$ row spacing $\left(\mathrm{T}_{6}\right)$ and lower under $90 \mathrm{~cm}$ row spacing $\left(\mathrm{T}_{10}\right)$. At initial period to 90 DAP, dry matter accumulation was found lower there after it was increased drastically due to development number of leaves and leaf area.

This was attributed to better growth of plant in terms of plant height. Similarly, Shinde et al., (2000) and Rehman et al., (2013) observed higher dry matter accumulation in plant under dual row planting.

\section{Sugar yield}

Growing of sugarcane with two eye budded setts with dual row planting $(30 \mathrm{~cm}-150 \mathrm{~cm}$ $30 \mathrm{~cm}$ ) recorded significantly higher sugar yield (15.2 $\left.\mathrm{t} \mathrm{ha}^{-1}\right)$ and it was on par with the two eye budded setts with paired row $(60 \mathrm{~cm}$ $120 \mathrm{~cm}-60 \mathrm{~cm})$ planting $\left(14.2 \mathrm{t} \mathrm{ha}^{-1}\right)$ and two eye budded setts with wide row $(120 \mathrm{~cm})$ planting (13.9 $\left.\mathrm{t} \mathrm{ha}^{-1}\right)$.

However, the sugar yield was on par with planting of sugarcane with single eye budded setts and bud chip seedling with different planting geometries (Table 2). Whereas, planting of sugarcane with three budded setts (conventional planting) recorded significantly lower sugar yield (10.4). The increased cane and sugar yield might be due to better light interception, greater availability of moisture, more aeration to individual setts and increased plant population which led to better tillering tiller retention, taller canes and increased cane weight at harvest over the rest of plant geometries. Similarly, Patel and Patel(2014) reported that planting of sugarcane with two budded setts was found to be significantly superior in increasing number of millable canes, cane and sugar yield over three and single budded setts. 


\section{Quality parameters}

The quality parameters of sugarcane viz., brix, pol, purity co-efficient and commercial cane sugar did not differ significantly as influenced by the establishment techniques and planting geometries (Table 3) but higher values recorded in two eye budded setts with dual row planting $(19.2,16.8,87.5$ and $11.5 \%$, respectively). Non-significant results might be ascribed to stable genetic character of the variety as well as similar environmental conditions. The findings are similar to those of Ruk et al., (2014), Maqsood et al., (2005), Singh et al., (1999) and Shinde et al., (2001)who reported non-significant effect of row spacing on brix percentage.

Table.1 Number of leaves per plant, Dry matter accumulation in leaf, stem and total in sugarcane as influenced by different establishment techniques and planting geometries

\begin{tabular}{|c|c|c|c|c|}
\hline \multirow[t]{2}{*}{ Treatments } & \multirow{2}{*}{$\begin{array}{c}\text { Number of } \\
\text { leaves } \\
\left.\text { plant }^{-1}\right)\end{array}$} & \multicolumn{3}{|c|}{$\begin{array}{c}\text { Dry matter accumulation }\left(\mathrm{g} \text { plant }^{-1}\right) \text { at } \\
\text { harvest }\end{array}$} \\
\hline & & Leaf & Stem & Total \\
\hline $\begin{array}{l}T_{1} \text { : Single eye budded setts with wide row } \\
\text { planting }(120 \mathrm{~cm} \text { furrow })\end{array}$ & 18.0 & 62.5 & 323.8 & 386.3 \\
\hline $\begin{array}{l}T_{2} \text { : Single eye budded setts with paired row } \\
\text { planting }(60 \mathrm{~cm}-120 \mathrm{~cm}-60 \mathrm{~cm})\end{array}$ & 18.3 & 62.7 & 324.8 & 387.5 \\
\hline $\begin{array}{l}T_{3} \text { : Single eye budded setts with dual row } \\
\text { planting }(30 \mathrm{~cm}-150 \mathrm{~cm}-30 \mathrm{~cm})\end{array}$ & 18.3 & 63.2 & 325.0 & 388.2 \\
\hline $\begin{array}{l}\mathrm{T}_{4}: \text { Two eye budded setts with wide row } \\
\text { planting }(120 \mathrm{~cm})\end{array}$ & 19.7 & 68.1 & 333.8 & 401.9 \\
\hline $\begin{array}{l}T_{5}: \text { Two eye budded setts with paired row } \\
\text { planting }(60 \mathrm{~cm}-120 \mathrm{~cm}-60 \mathrm{~cm})\end{array}$ & 20.0 & 68.5 & 341.6 & 410.1 \\
\hline $\begin{array}{c}\mathrm{T}_{6}: \text { Two eye budded setts with dual row } \\
\text { planting }(30 \mathrm{~cm}-150 \mathrm{~cm}-30 \mathrm{~cm})\end{array}$ & 20.7 & 72.6 & 342.1 & 414.6 \\
\hline $\begin{array}{l}\mathrm{T}_{7} \text { : Bud chip seedling with wide row } \\
\text { planting (120 cm furrow) }\end{array}$ & 17.0 & 62.0 & 322.5 & 384.5 \\
\hline $\begin{array}{c}\mathrm{T}_{8}: \text { Bud chip seedling with paired row } \\
\text { planting }(60 \mathrm{~cm}-120 \mathrm{~cm}-60 \mathrm{~cm})\end{array}$ & 17.3 & 62.1 & 323.2 & 385.3 \\
\hline $\begin{array}{l}\mathrm{T}_{9} \text { : Bud chip seedling with dual row } \\
\text { planting }(30 \mathrm{~cm}-150 \mathrm{~cm}-30 \mathrm{~cm})\end{array}$ & 17.7 & 62.6 & 323.5 & 386.1 \\
\hline $\begin{array}{l}\mathrm{T}_{10}: \text { Three eye budded setts with } \\
\text { conventional planting }(90 \mathrm{~cm})\end{array}$ & 17.0 & 61.4 & 320.6 & 382.0 \\
\hline S.Em. \pm & 0.8 & 2.2 & 4.4 & 3.6 \\
\hline C.D. $(P=0.05)$ & 2.3 & 6.6 & 13.2 & 10.6 \\
\hline
\end{tabular}


Table.2 Yield parameters and sugar yield of sugarcane as influenced by different establishment techniques and planting geometries

\begin{tabular}{|c|c|c|c|c|}
\hline Treatments & $\begin{array}{l}\text { Inter nodal } \\
\text { length }(\mathrm{cm})\end{array}$ & $\begin{array}{c}\text { Cane } \\
\text { diameter }(\mathrm{cm})\end{array}$ & $\begin{array}{c}\text { Green } \\
\text { biomass } \\
\text { yield } \\
\left(\mathbf{t ~ h a}^{-1}\right)\end{array}$ & $\begin{array}{l}\text { Sugar yield } \\
\left(\mathrm{t} \mathrm{ha}^{-1}\right)\end{array}$ \\
\hline $\begin{array}{l}T_{1} \text { : Single eye budded setts with wide } \\
\text { row planting }(120 \mathrm{~cm} \text { furrow) }\end{array}$ & 11.1 & 2.6 & 13.6 & 12.2 \\
\hline $\begin{array}{l}T_{2}: \text { Single eye budded setts with paired } \\
\text { row planting }(60 \mathrm{~cm}-120 \mathrm{~cm}-60 \mathrm{~cm})\end{array}$ & 11.2 & 2.7 & 13.9 & 12.7 \\
\hline $\begin{array}{l}T_{3} \text { : Single eye budded setts with dual } \\
\text { row planting }(30 \mathrm{~cm}-150 \mathrm{~cm}-30 \mathrm{~cm})\end{array}$ & 11.3 & 2.7 & 14.2 & 12.8 \\
\hline $\begin{array}{l}\mathrm{T}_{4} \text { : Two eye budded setts with wide row } \\
\text { planting }(120 \mathrm{~cm})\end{array}$ & 11.5 & 2.7 & 14.4 & 13.9 \\
\hline $\begin{array}{l}\mathrm{T}_{5}: \text { Two eye budded setts with paired } \\
\text { row planting }(60 \mathrm{~cm}-120 \mathrm{~cm}-60 \mathrm{~cm})\end{array}$ & 11.5 & 2.7 & 15.0 & 14.2 \\
\hline $\begin{array}{l}\mathrm{T}_{6} \text { : Two eye budded setts with dual row } \\
\text { planting }(30 \mathrm{~cm}-150 \mathrm{~cm}-30 \mathrm{~cm})\end{array}$ & 11.7 & 2.8 & 16.2 & 15.2 \\
\hline $\begin{array}{c}\mathrm{T}_{7} \text { : Bud chip seedling with wide row } \\
\text { planting }(120 \mathrm{~cm} \text { furrow })\end{array}$ & 11.0 & 2.6 & 12.8 & 10.9 \\
\hline $\begin{array}{l}T_{8} \text { : Bud chip seedling with paired row } \\
\text { planting }(60 \mathrm{~cm}-120 \mathrm{~cm}-60 \mathrm{~cm})\end{array}$ & 11.0 & 2.6 & 13.2 & 11.6 \\
\hline $\begin{array}{l}T_{9} \text { : Bud chip seedling with dual row } \\
\text { planting }(30 \mathrm{~cm}-150 \mathrm{~cm}-30 \mathrm{~cm})\end{array}$ & 11.0 & 2.6 & 13.4 & 12.1 \\
\hline $\begin{array}{l}\mathrm{T}_{10} \text { :Three eye budded setts with } \\
\text { conventional planting }(90 \mathrm{~cm})\end{array}$ & 10.8 & 2.3 & 11.9 & 10.4 \\
\hline S.Em. \pm & 0.3 & 0.1 & 0.6 & 0.7 \\
\hline C.D. $(P=0.05)$ & NS & NS & 1.9 & 2.2 \\
\hline
\end{tabular}

NS- Not Significant 
Table.3 Quality parameters and sugar yield of sugarcane as influenced by different establishment techniques and planting geometries at harvest

\begin{tabular}{|c|c|c|c|c|}
\hline Treatments & $\begin{array}{l}\text { Brix } \\
(\%)\end{array}$ & $\begin{array}{l}\text { Sucrose } \\
\qquad(\%)\end{array}$ & $\begin{array}{l}\text { Purity co- } \\
\text { efficient } \\
(\%)\end{array}$ & $\begin{array}{l}\text { CCS } \\
(\%)\end{array}$ \\
\hline $\begin{array}{c}T_{1} \text { : Single eye budded setts with wide } \\
\text { row planting }(120 \mathrm{~cm} \text { furrow })\end{array}$ & 18.5 & 15.9 & 85.9 & 10.8 \\
\hline $\begin{array}{l}\mathrm{T}_{2}: \text { Single eye budded setts with paired } \\
\text { row planting }(60 \mathrm{~cm}-120 \mathrm{~cm}-60 \mathrm{~cm})\end{array}$ & 18.5 & 16.1 & 87.0 & 11.0 \\
\hline $\begin{array}{l}T_{3} \text { : Single eye budded setts with dual } \\
\text { row planting }(30 \mathrm{~cm}-150 \mathrm{~cm}-30 \mathrm{~cm})\end{array}$ & 18.8 & 16.2 & 86.1 & 11.0 \\
\hline $\begin{array}{l}\mathrm{T}_{4} \text { : Two eye budded setts with wide row } \\
\text { planting }(120 \mathrm{~cm})\end{array}$ & 18.9 & 16.5 & 87.3 & 11.3 \\
\hline $\begin{array}{l}\mathrm{T}_{5}: \text { Two eye budded setts with paired } \\
\text { row planting }(60 \mathrm{~cm}-120 \mathrm{~cm}-60 \mathrm{~cm})\end{array}$ & 19.0 & 16.6 & 87.3 & 11.4 \\
\hline $\begin{array}{l}T_{6}: \text { Two eye budded setts with dual row } \\
\text { planting }(30 \mathrm{~cm}-150 \mathrm{~cm}-30 \mathrm{~cm})\end{array}$ & 19.2 & 16.8 & 87.5 & 11.5 \\
\hline $\begin{array}{c}\mathrm{T}_{7} \text { : Bud chip seedling with wide row } \\
\text { planting (120 cm furrow) }\end{array}$ & 18.2 & 15.2 & 83.5 & 10.2 \\
\hline $\begin{array}{c}\mathrm{T}_{8}: \text { Bud chip seedling with paired row } \\
\text { planting }(60 \mathrm{~cm}-120 \mathrm{~cm}-60 \mathrm{~cm})\end{array}$ & 18.3 & 15.5 & 84.6 & 10.5 \\
\hline $\begin{array}{l}T_{9}: \text { Bud chip seedling with dual row } \\
\text { planting }(30 \mathrm{~cm}-150 \mathrm{~cm}-30 \mathrm{~cm})\end{array}$ & 18.4 & 15.8 & 85.8 & 10.7 \\
\hline $\begin{array}{l}\mathrm{T}_{10}: \text { Three eye budded setts with } \\
\text { conventional planting }(90 \mathrm{~cm})\end{array}$ & 18.1 & 15.2 & 83.9 & 10.2 \\
\hline S.Em. \pm & 0.6 & 0.6 & 2.9 & 0.5 \\
\hline C.D. $(P=0.05)$ & NS & NS & NS & NS \\
\hline
\end{tabular}


Table.4 Economics of sugarcane as influenced by different establishment techniques and planting geometries

\begin{tabular}{|c|c|c|c|c|}
\hline \multirow[t]{2}{*}{ Treatments } & $\begin{array}{c}\text { Cost of } \\
\text { cultivation }\end{array}$ & $\begin{array}{c}\text { Gross } \\
\text { returns }\end{array}$ & $\begin{array}{l}\text { Net } \\
\text { returns }\end{array}$ & \multirow[t]{2}{*}{$\begin{array}{l}\text { Benefit cost } \\
\text { ratio }(B: C)\end{array}$} \\
\hline & \multicolumn{3}{|c|}{$\left(\mathrm{Rs} \mathbf{h a}^{-1}\right)$} & \\
\hline $\begin{array}{l}\mathrm{T}_{1} \text { : Single eye budded setts with wide } \\
\text { row planting }(120 \mathrm{~cm} \text { furrow })\end{array}$ & 121633 & 359667 & 238900 & 3.0 \\
\hline $\begin{array}{l}T_{2}: \text { Single eye budded setts with paired } \\
\text { row planting }(60 \mathrm{~cm}-120 \mathrm{~cm}-60 \mathrm{~cm})\end{array}$ & 124733 & 367467 & 245200 & 3.0 \\
\hline $\begin{array}{l}\mathrm{T}_{3} \text { : Single eye budded setts with dual } \\
\text { row planting }(30 \mathrm{~cm}-150 \mathrm{~cm}-30 \mathrm{~cm})\end{array}$ & 125700 & 368940 & 246390 & 3.0 \\
\hline $\begin{array}{c}\mathrm{T}_{4} \text { : Two eye budded setts with wide row } \\
\text { planting }(120 \mathrm{~cm})\end{array}$ & 123183 & 385320 & 259620 & 3.1 \\
\hline $\begin{array}{l}\mathrm{T}_{5}: \text { Two eye budded setts with paired } \\
\quad \text { row planting }(60 \mathrm{~cm}-120 \mathrm{~cm}-60 \mathrm{~cm})\end{array}$ & 126750 & 390780 & 264030 & 3.1 \\
\hline $\begin{array}{c}\mathrm{T}_{6}: \text { Two eye budded setts with dual row } \\
\text { planting }(30 \mathrm{~cm}-150 \mathrm{~cm}-30 \mathrm{~cm})\end{array}$ & 127683 & 411493 & 280760 & 3.2 \\
\hline $\begin{array}{c}\mathrm{T}_{7} \text { : Bud chip seedling with wide row } \\
\text { planting }(120 \mathrm{~cm} \text { furrow })\end{array}$ & 117850 & 344500 & 226650 & 2.9 \\
\hline $\begin{array}{c}\mathrm{T}_{8}: \text { Bud chip seedling with paired row } \\
\text { planting }(60 \mathrm{~cm}-120 \mathrm{~cm}-60 \mathrm{~cm})\end{array}$ & 119600 & 353600 & 234000 & 3.0 \\
\hline $\begin{array}{l}\mathrm{T}_{9}: \text { Bud chip seedling with dual row } \\
\text { planting }(30 \mathrm{~cm}-150 \mathrm{~cm}-30 \mathrm{~cm})\end{array}$ & 120667 & 359147 & 238480 & 3.0 \\
\hline $\begin{array}{l}\mathrm{T}_{10} \text { : Three eye budded setts with } \\
\text { conventional planting }(90 \mathrm{~cm})\end{array}$ & 112933 & 318933 & 206000 & 2.9 \\
\hline S.Em. \pm & - & 13444 & 10858 & $\mathbf{0 . 0 3}$ \\
\hline C.D. $(P=0.05)$ & - & 39944 & 32263 & 0.10 \\
\hline
\end{tabular}

Similarly, Ullah et al., (2011), Ghaffar et al., (2012) and Mahadevaswamy and Matrin (2002), observed that different planting techniques did not affect pol contents. Further, Ghaffar et al., (2012), Hussain et al., (2005) While Patel and Patel (2014) also witnessed that purity was non-significantly affected by different row spacings. CCS \% is one of the aspects of cane quality, the final goal to achieve optimum sugar yield. The real cane quality is reflected by its commercial cane sugar (CCS) percentage. Commercial cane sugar was not significantly affected by different planting geometries. Under different planting configurations commercial cane sugar (CCS \%) ranged from $14.03 \%$ to $14.18 \%$.
Results fall in line with those of Ullah et al., (2011), Sajjad et al., (2014) and Roodagi et al., (2001) stated that establishment techniques failed to affect CCS \%

\section{Economics}

Maximum cost of cultivation, gross returns, net returns and BC ratio (Rs.127683, Rs.411493, Rs.280760 ha ${ }^{-1}$ and 3.2, respectively) was recorded with two eye budded setts with dual row planting $(30 \mathrm{~cm}-$ $150 \mathrm{~cm}-30 \mathrm{~cm}$ )and it was on par with the two eye budded setts with paired row $(60 \mathrm{~cm}-120$ $\mathrm{cm}-60 \mathrm{~cm}$ ) planting (Rs. 126750, Rs.390780, Rs.264030 ha ${ }^{-1}$ and 3.1, respectively) and two 
eye budded setts with wide row $(120 \mathrm{~cm})$ planting (Rs.123183,Rs.385320,Rs. 259620 $\mathrm{ha}^{-1}$ and 3.1, respectively). Whereas, planting of sugarcane with three budded setts (conventional planting) recorded significantly least cost of cultivation, gross returns, net returns per hectare and BC ratio (Rs.112933, Rs.318933, Rs.206000 $\mathrm{ha}^{-1}$ and 2.8, respectively) (Table 4). This was due to the higher yield realized in these treatments which resulted in higher gross returns. Higher cane yield contributed to higher net returns and $B: C$ ratio. These results are in line with Saxena et al., (2012). Thus, the two budded setts with dual row planting was superior to the conventional planting in saving the resources

Results of this study indicated that, planting of sugarcane with two eye budded setts with dual rows $(30 \mathrm{~cm}-150 \mathrm{~cm}-30 \mathrm{~cm})$ recorded higher sugar yield in addition to net returns and B:C ratio followed by two eye budded setts with paired row $(60 \mathrm{~cm}-120 \mathrm{~cm}-60 \mathrm{~cm})$ planting and two eye budded setts with wide row (120 $\mathrm{cm})$ planting. Further, this technique may help to reduce the cost of production and also suitable for mechanical harvesting.

\section{References}

Anonymous, 2015, Area, production and productivity of sugarcane in India, $\mathrm{Co}$ operative Sugar, 47(3): 1-2.

Anonymous, 2015a, Annual progress report, Indian Institute of Sugarcane Research, Lucknow, India.

Ghaffar, A., Ehsanullah., Akbar, N., Khan, S. H., Jabran, K., Hashmi, R. Q., Iqbal, A. and Ali, M. A., 2012, Effect of trench spacing and micronutrients on growth and yield of sugarcane (Saccharum officnarum L.). Australian J. Crop Sci., 6(1):1-9.

Gomez, K. A. and Gomez, A. A., 1984, Statistical Procedures for Agricultural
Research, $2{ }^{\text {nd }}$ Edn..John Wiley and Sons. New York, p. 639.

Hussain, M. S., Singh, V. P. and Sudhirkumar, S., 2005, Effect of variety and wider row spacing on plant population, cane yield and juice quality. Bhartiya Sugar, 29(3): 34-37.

Jackson, M. L., 1973, Soil Chemical Analysis. Prentice hall of India (Pvt.), New Delhi, pp. 67-214.

Lindsay W L and Norvel WA. 1978. Development of DTPA soil test for $\mathrm{Zn}$, $\mathrm{Fe}, \mathrm{Mn}$ and $\mathrm{Cu}$. Soil Sci. Society of American J., 42: 421-428.

Mahadevaswamy, M. G. T. and Martin, 2002, Production potential for wide row sugarcane inter-cropped with aggregatum onion. Indian J. Agron., 47 (3): 361-366.

Maqsood, M., Iqbal, M. and Tayyab, M., 2005, Comparative productivity performance of sugarcane sown in different planting patterns at farmer's field. Pakisthan J. Agric. Sci., 42: 3-4.

Patel, D. and Patel, R., 2014, Influence of sett size, seed rate and sett treatment on yield and quality of sugarcane. J. Life Sci., 9(1): 55-57.

Rehman, A-UR., Ehsanullah, Ahmad, R. and Jabbar, A., 2013, Interactive study of row spacing $\mathrm{s}$ and foliar application of macro and micro nutrients on growth, yield and quality of sugarcane (Saccharum officinarum L.) .Pakisthan J. Bot., 45 (2): 427-433.

Roodagi, L. I., Itnal, C. J., Biradar, D. P. and Angadi, S. A., 2001, Leaf area index, light transmission ratio and sugar yield of sugarcane as influenced by planting methods and intercropping systems. Bharatiya Sugar, 26 (10): 39-45.

Ruk, A. S., Kandhro, M. N., Baloch, S. K., Baloch, S. and Baloch, A. B., 2014, Impact of sett placement methods and row direction growth and yield of sugarcane variety LRK-2001. Persian 
Gulf Crop Protection, (3):53-69.

Sajjad, M., Bari, A., Nawaz, M. and Iqbal, S., 2014, Effect of planting pattern and nutrient management on yield of spring planted sugarcane. Sarhad J. Agric., (30): 67-71.

Sastry, S.K. and Venkatachari, A., 1960, Nutrient requirements of sugarcane at Rudrur, Andhra Pradesh. Proc. 4th All India Conf. Sugarcane Researchers and Dev. Workers, p. 146.

Saxena, Vinkar Patel and Rampal, Y. R., 2012, Evaluation of setts and settlings planting in the coastal belt of Tamilnadu. Co-operative sugar, 15: 25-29.

Shinde, S. H., Dahiwalkar, S. D. and Berad, S. M., 2000, Response of sugarcane to planting technique and fertigation through drip. Bharatiya Sugar, 25(3): 19-24.
Shinde, S. H., Dahiwalkar, S. D. and Berad, S. M., 2001, Influence of planting technique and fertigation on sugarcane economics and quality. Indian Sugar, $51(2): 17-21$.

Singh, A. K., Lal, M. and Prasad, S. R., 2006, Effect of row spacing and nitrogen on ratoonability of early maturing high sugar genotypes of sugarcane (Saccharum spp. hybrid). Indian $J$. Agril. Sci., 76(2): 108-10.

Singh, S., Saini, L. K., Garcha, A. I. S., Singh, M. and Uppal, S. K., 1999, Effect of planting geometry on the productivity of sugarcane. Bhartiya Sugar, 31 (56): $19-22$

Ullah, E., Jabran, K., Jamil, M. and Ghaffar, A., 2011, Optimizing the sugarcane row spacing and seeding density to improve its yield and quality. Crop $\& E n v .,(2): 1-5$.

\section{How to cite this article:}

Maruthi, D. Krishnamurthy, Y.M. Ramesh, B.M. Chittapur and Ashokkumar Gaddi. 2019. Growth, Sugar Yield, Quality and Economics of Sugarcane under Different Establishment Techniques and Planting Geometries. Int.J.Curr.Microbiol.App.Sci. 8(11): 485-493.

doi: https://doi.org/10.20546/ijcmas.2019.811.059 